\title{
Designing digital library as a facilities to support Open and Distance learning (ODL) student: a case in Universitas Terbuka Indonesia
}

By

\author{
ASNAH MN, SITI SYAMSIAH, BENNY A. PRIBADI \\ Limbongasnahlimbong@ecampus.ut.ac.id \\ SitiSyamsiahsiti@ecampus.ut.ac.id \\ Benny A. Pribad iagus.benny@gmail.com
}

The aim of this study is to elaborate the effectiveness of digital library to support open and distant learning students. Digital libary is required to support Open and Distance Learning (ODL) students to get learning materials in their learning process. This descriptive study involved Students Expert of IT, Librarians as respondents. The respondents provided information and data regarding the use of the digital library to support their learning process. Observation and interview were used as a technique for collecting data and information. Besides, this study used secondary data is related to the objective of the study-to elaborate the effectives of using distance learning in ODL. The result of this study is indicated that the majority of the open and distant students used the components of availbale digital library such as Virtual Reading Room (RBV), e-repository, e-resource and Open Education Resource (OER) to support their learningactivities.

Keywords: Distance learning, components of digital library, and ODL

\section{Intruduction}

Universitas Terbuka (UT) one of the Indonesia state universities, implements Open and Distant Learning (ODL) to distribute the course content to the students. It is necessary for the ODL students to be active and self directed in persuing learning activities. The ODL student have to find and selects their materials in order to achieve predetermined knowledge and skills. Besides the ODL student have to access various available materials and media to conduct their learning process. UT users variety of instructional media and materials such as: printed modular system, video programs, audio programs, multimedia, and web. This media and materials provided content-knowledge, skill, and attitude to be learned in order to achived the instructional goals and objectives. Printed modular system is used as themain 
materials to be learned by the student. All of the media and materials is integrated in one system which is called digital libary. In order to study the course content, the students have to access the provided digital libary. This present article will elaborate the use of the digital library to support ODL students to master their course materials.

\section{ResearchProblem}

1.Is the use of digital library provided by UT enhance student learning process?

2.How the student react to the digital library facility?

\section{III.ResearchMethod}

This study implemented the descriptive research methode. Continous observation and interview trough internet were using to gather the necessary data and information. Eighty student from different study programs of UT were involved as participant in this study. They are active users of digital library of UT in searching, browsing, note taking and discussing the course content available in UT digital library. Observation and interview guide were used to get information regarding the effectiveness of using digital library and the students reaction to the use of digital library. The collected data were analyzed qualitatively to reveal the research questions.

\section{IV.Result \&Discussion}

1. Library as a LearningResource

The library is a strategic part of the university. The library must be able to provide collections needed for the entire academic community. The Collections in the library include textbooks, journals, e-books, e-journals, CD collections, online collections, and a number of manuscripts. This collections have to be utilized to support the academic of students, lectures and also tutors.

How to search in various libraries has undergone a change, initially in 1990 students and lecturers had to visit physically the search for collections was done by searching the catalog card, but in 2000 the conditions had changed. Library users begin to be able to access library collections wherever they are. Catalogues that can be accessed anywhere without time limitation are called online catalogue. Online catalogue are very helpful for the users by using the catalogue the student or the users will be able to browse and find the needed learning resourses easily and quickly.

Along with the development of technology, text books and print journals began to change. Currently various-collections of online or e-journal, journals, and e-books or digital books is becoming popular in the library. This novel facilities makes it easier for the library users to take advantage of all existing collections. Through advanced facilities and technologies the library as a source of learning materials will be able to improve the academic quality in various field ofstudy. 
2. Open University Library(UT)

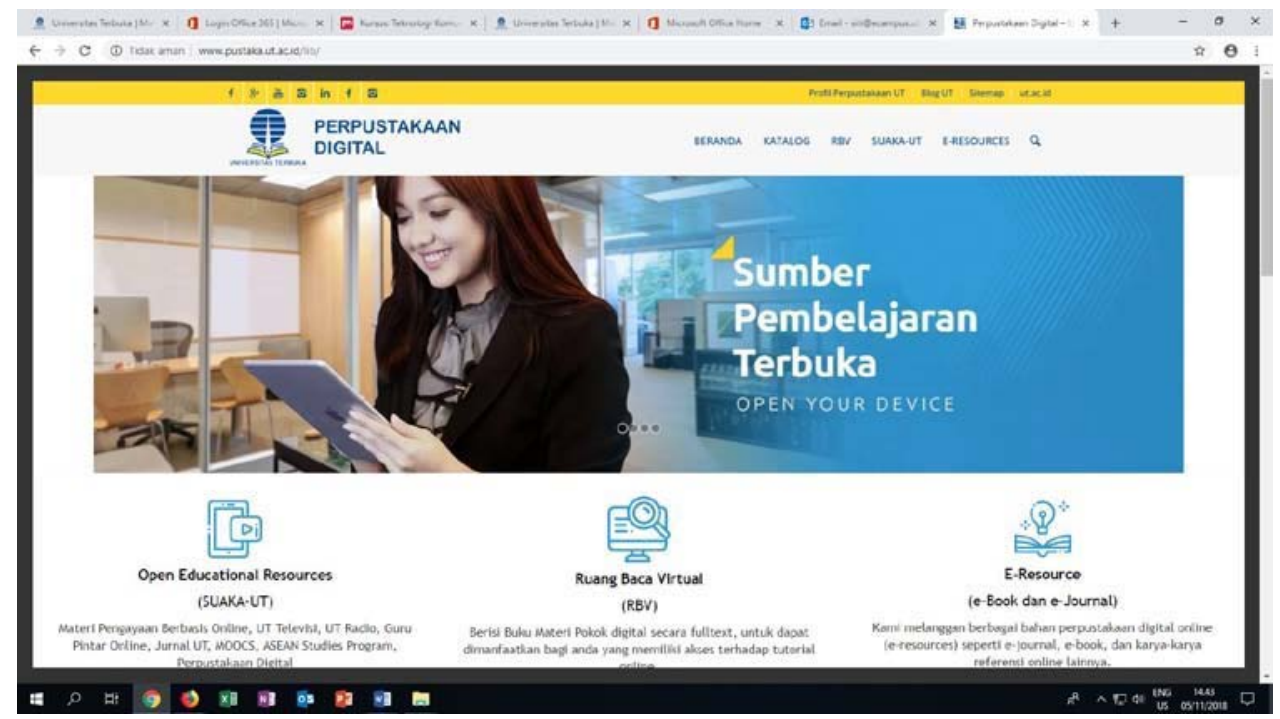

Sumber : $\underline{\text { http://www.ut.ac.id }}$

UT Provides digital library that can be used by the student to find the relevant learning materials to study. The digital library of UT consists of the following components:

1. Online catalog (OPAC) as a means of searching text books ande-books.

2. e-journal, is an indexed indexdatabase.

3. e-repository, is a database of scientific works produced by the UT academic community.

4. RBV or Virtual Reading Room that contains all the basic material books available in all study programs atUT

5. SUAKA -UT is a collection of OER-based materials in the form of material based on online, UT-TV, UT-Radio, Moocs

6. e-newspaper, national digital newspaper.

7. e-magazine, a national digitalmagazine.

In addition the UT digital library facilities also connected with the Indonesian National Library, Indonesia One Search (IOS) and other facilities for accredited journals in the ministry of technology research and higher education.

With the existing facilities UT students have flexibility in the learning process in terms of time and from the content of the learning aid material chosen.

UT Digital library has the number of textbook collections reaching 40,000 books, 3,700 e-books, also e-journal collections, e-newspapers, e-magazines, hundreds of collections of non-print teaching materials in audio-video format, enriching learning material in dry lab format and CAI building UT's digital library as a center for learning resources is ready to be accessed by all of the UT academics, lecturers as well as students who spread across 40 UPBJJ throughout Indonesia as well as UT students abroad. 
Given the distribution of UT students across Indonesia with different search capabilities. Digital Library -UT also prepares search techniques that can accommodate all the users to access UT course materials. The first search technique (1) in the form of an online catalog, users can access the entire collection by entering keywords, (2) conventional catalog techniques, users choose the desired collection based on a list of all existing collections. Both of these tracking techniques help the students from the collections retrieval speedneeded.

As a digital library. The use of UT library is very high, this can be seen in the following on following the web visitor statistics(pustaka.ut.ac.id)

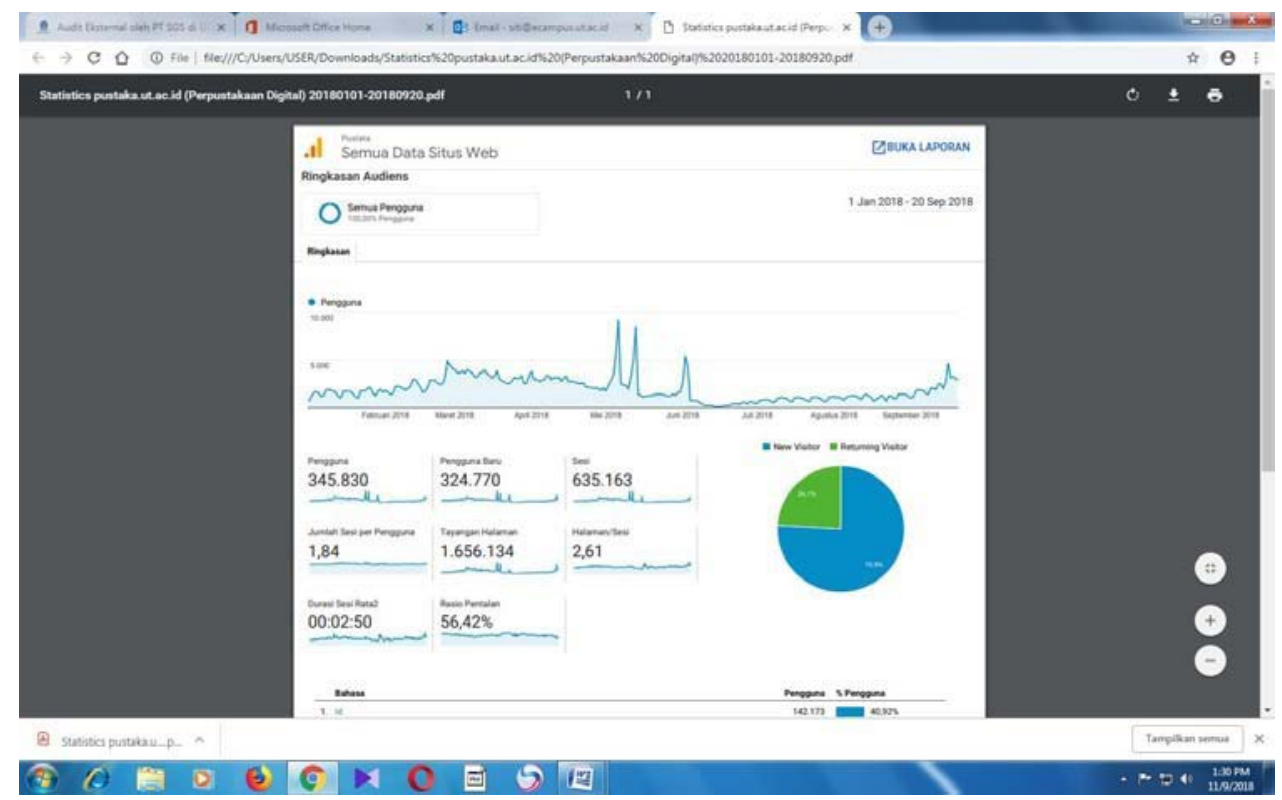

Source: http://www.pustaka.ut.ac.id

Based on data from 1 January to 30 September 2018, there were 1,656,134 users accessing. A very large number means that there are enough users, students, lecturers, tutors and the community to use the information on the UT library website. For collection facilities in the UT library, there are facilities that can be accessed by the public for free, namely Opac (Online Public Catalog), OER (Open Education Resources), e-Repository. As for e-books, e-journals, rbv, e-magazines, enewspapers can be accessed only for students and employees, based on the student's number (NIM) and employee's number (NIP).

The results of interview with the students noted put graphics that the UT's digital library greatly helped the students learning process. Mainly the RBV facility because the subject matter book arrived late then the RBV was very helpful for following the tutorial that was carried out. 
The results of the IT expert interview, noted that the majority of the students use RBV facilities to get required knowledge and information. The data indicateds that students who access this learning facilities are very high. This condition shows that students have been able to use technology for learningpurposes.

In addition to collections in the form of textbooks, e-books and e-journals, UT students as students who take part in the distance learning process can also utilize the digital library. The students read the BMP in the virtual reading room (RBV). Through this RBV students can read all the main material books contained in the curriculum of their study program. From the statistical data, it shows the high utilization of rbv by students and lecturers as well as tutors.

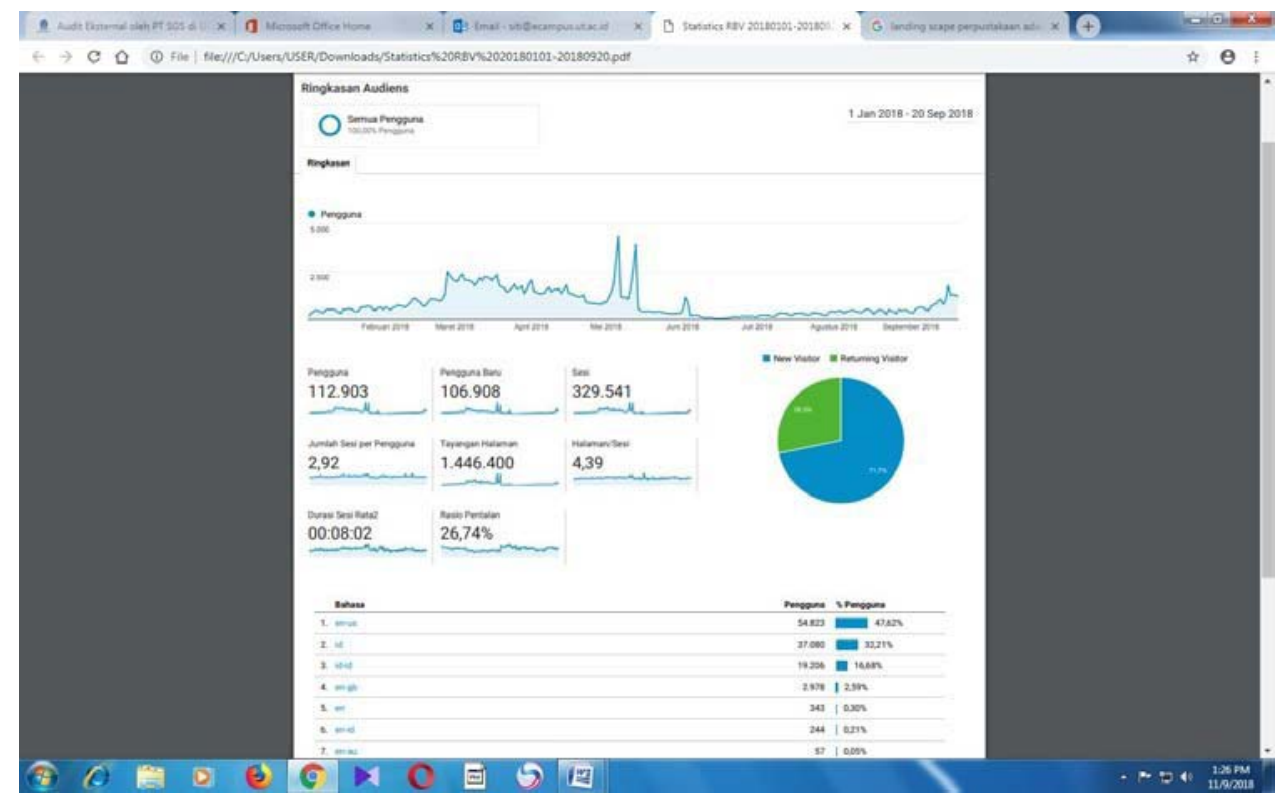

Source: $\underline{\text { http://www.ut.ac.id }}$

From the above data, RBV users can reach 106,908 while the number of features used reaches $1,446,400$. Of these, it is indicated that the utilization of rbv is very high. RBV can be used by students and lecturers for 24 hours, so wherever students are located can study indefinitely.

Other facilities provided by digital library -UT are UT-TV. At this UT-TV facility students can learn through videos that can be enjoyed according to their needs, along with statistical data that shows the number of users access reaches 384,343 users. 


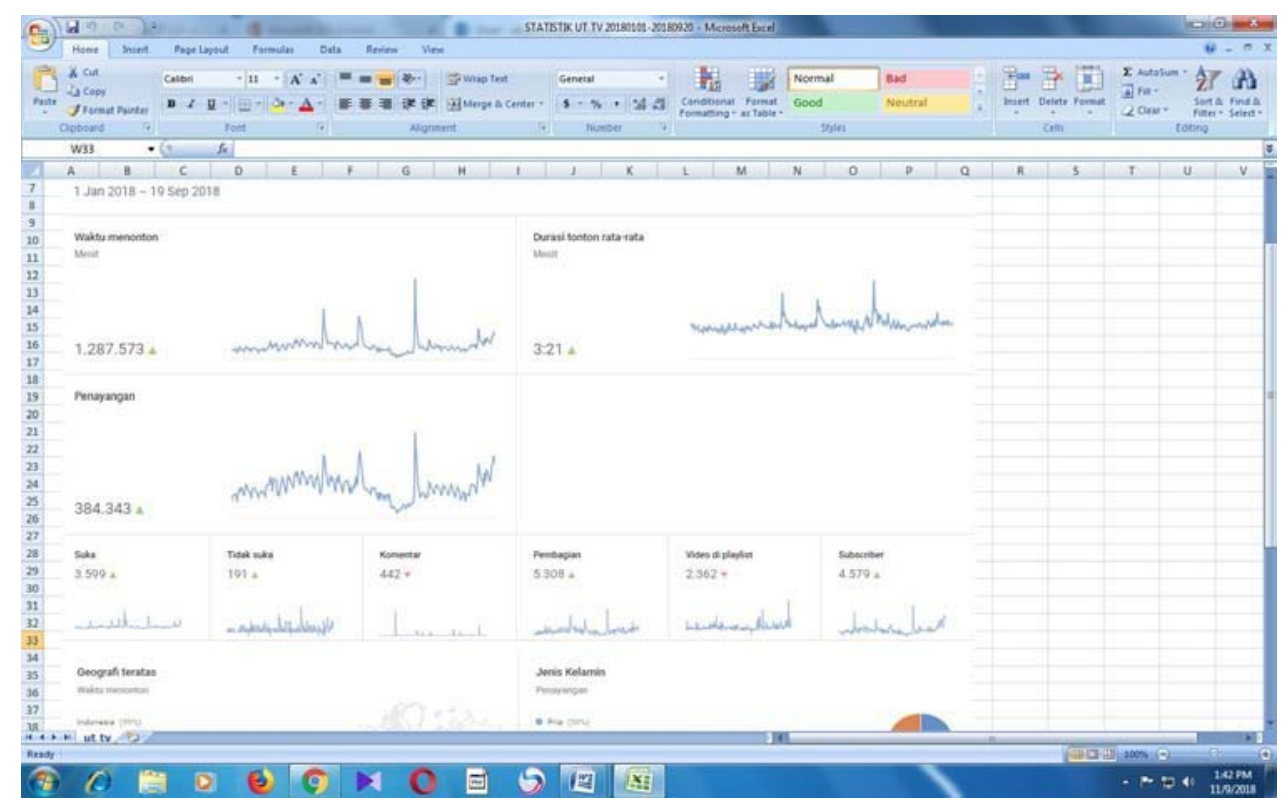

Source: $\underline{\text { http://www.ut.ac.id }}$

From the statistical data described in the form of statistical data on visitors to digital libraries, OPAC, RBV, UT-TV showing digital libraries UT has been able to realize its vision of becoming a superior library in disseminating information about open and distance education in Indonesia.

\section{Digital Library -UT Assistance Strategy for Students}

Some people say learning resources can be easily searched on the internet. But it will be difficult for someone to determine the information needed if it is in billions of information that must be sorted out, which can finally be enjoyed. Digital library -UT has prepared all software and hardware devices for students so that they can use the libraryeasily.

As a center for learning resources, digital library -UT always updates existing collections, this is based on revisions to the main teaching material carried out by the faculty / study program every 4 years. The revision of teaching materials will have implications for changes in the BMP writing reference book, changes in virtual reading rooms, changes to non-print teaching materials, changes to the dry lab if the subject has practical content, changes to radio enrichment material and UT-TV. Collections in the digital library - UT is very dynamic in adjusting existing curriculum changes.

To make it easier for students to obtain information on library collections can be accessed through the UT Handbook - for students. The information contained in online format pocket books as well as easy to carry print formats helps students to be able to access UT's digital library. Understanding the use of UT student pocket books will be guided to study without limitation of time andplace. 
Source: http://www.ut.ac.id

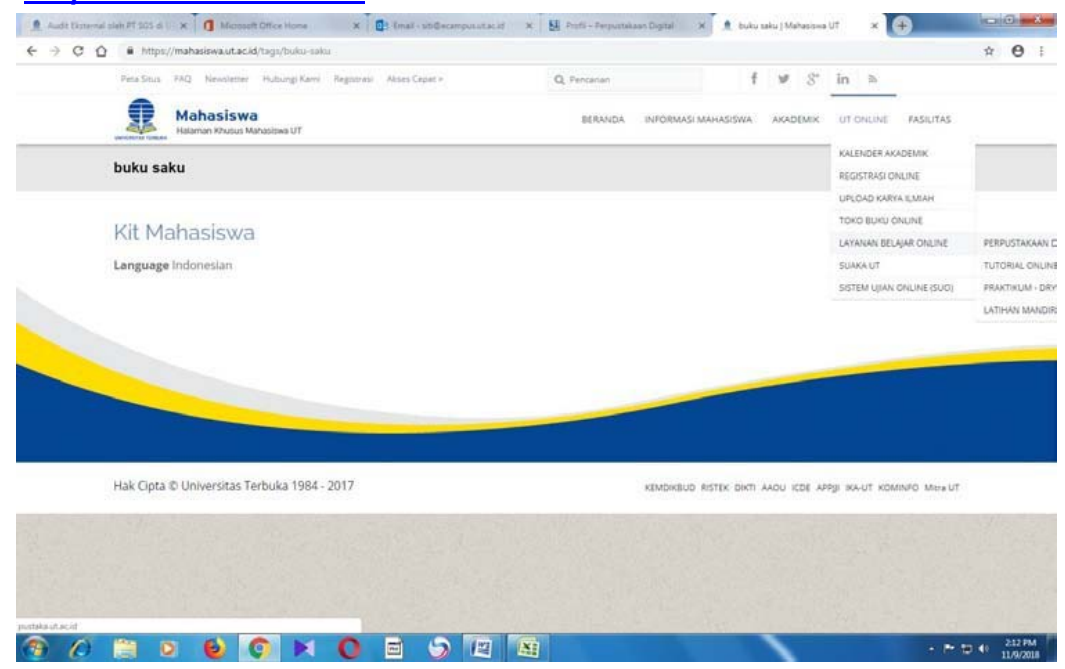

Source ://www.ut.ac.id

\section{V.Conclusion}

The digital library is designed to support the ODL learning process. The study showed that this learning facility contributes significantly the student learning activities such as searching; browsing; downloading; learning and writing the academic assigments. The majority of the students feel happy to use the digital library provided by the Universitas Terbuka. It is necessary for UT to improve their service the use of digitallibrary.

To design digital libraries, not only software is needed, namely library applications that are user friendly, bandwidth is adequate, but also the content of library collections that are always updated is needed according to curriculum changes that occur in each study program.

\section{Reference}

Bajpai, R.P. 2004. Digital Libraries and Information Services. New Delhi : Shree

Davarajan, G. 2005. Library and Information Studies In The Digital Age.

New Delhi: E E P

Hardiningtyas, Tri. 2014. MembangunPerpustakaan Ideal (BungaRampai).

Yogyakarta : Smart WR

Moore, Michael G \& Greg Kearsley. 2012. Distance Education.A system View

Of Online Learning. USA : Wadsworth

Simonson, Michael R. 2012. Teaching and Learning at a Distance.

Foundation of Distance Education.Boston : Publishing Allyn\& Bac 